\title{
GEODETIC SURVEY AND MAPPING IN THE PURĀṆAS
}

\author{
K. Vidyata
}

\begin{abstract}
India's major contributions to astronomy, geometry, and other branches of mathematics and the remarkably creative exuberance of its culture is widely known from the Sanskrit scriptures. From the same scriptures we can infer much about the nature of cartography in its broadest sense, including cosmography, over much of the span of Indian history and we may reasonably suppose that some of the indigenous maps of the past several centuries carry on traditions of considerable antiquity.
\end{abstract}

This paper will bring to light the accurate methods of geodetic survey and mapping performed by our ancient scholars that have been recorded in our Purānas.

\section{INTRODUCTION:}

Geodetic surveying is the survey in which the curvature of the earth is taken into account and higher degree of accuracy in linear and angular observations is achieved. The geodetic surveys extend over large areas and lines connecting any two points on the surface of the earth are treated as arcs. For calculating their projected distances on the plans or maps, the correction for the earth's curvature is applied to the measured distances. These surveys are conducted with highest degree of accuracy to provide widely spaced control points on the earth surface for subsequent plane surveys. 
From the time of the Vedas the ancient Indians had good knowledge of surveying and cartography. For survey and cartography developed, during the Vedic period, equally in both the realms - in agrarian and administrative spheres and in the field of sacrificial science. The latter stressed and achieved the strictest accuracy and punctiliousness in them.

In the Brāhmanas we come across varieties of concepts of representation, though they are more marked for primitiveness and crudeness. The crudeness is due to the fact that just mere concepts are mentioned here, which might have had nothing to do with the entire picture and whole process and speed of chronological evolution.

The Śatapathabrāhmana is really a mine of information on Indian survey and cartography and on concepts of representation and primitive world map, not only of its own country but perhaps of the whole world. In due course the survey, drawing and construction of Vedis assumed the form of a separate full-fledged and rigorous science designated as the Sulbasūtras.

The Puranic period can be considered to be the Golden Age of survey and cartography. Just like the Vedic literature, the Purānas have also referred to the survey of the whole universe.

\section{SURVEYING IN THE PURĀṆAS :}

In the Matsyapurāna ${ }^{1}$, Sage Nārada ordains the sons of Dakṣa to first examine the extent of the universe, then carry on the work of creation : भुवः प्रमाणं सर्वत्र ज्ञात्वोर्ध्वमध्य एव च। In the same strain, the Varāha Purāna $a^{2}$ states that: Having said this he surveyed and measured the earth and sky.

Various Purannas have dealt with the apportionment of the whole earth into seven continents and again the divisions of those continents are also discussed. This shows that the ancient Indians 
had good concept of very large scale survey and measurement. The following lines of the Viṣnu Purāna $a^{3}$ establishes the above fact:

न हि पूर्वविसर्ग वै विषमे पृथिवीतले।

प्रविभागः पुराणां वा ग्रामाणां वा पुराभवत्॥

न सस्यानि न गोरक्ष्यं न कृषिर्न वणिक्पथः।

वन्यांत्प्रभृति मैत्रेय सर्वस्यैतस्य सम्भवः।

- Before this the surface of the earth was irregular and there was no boundary of villages and cities. There was no cultivation, no pasture, no highway for merchant; all these originated, $\mathrm{O}$ Maitreya, in the reign of the son of Vena.

Therefore, it can be concluded that the first survey was carried out in the time of Pṛthu (son of Vena).

The Brahmapurāna ${ }^{4}$, uses the term ganaka to imply engineers and surveyors simultaneously-

आनाय्य गणकान् $\ldots \ldots \ldots$ वास्तुविद्याविशारदैै।॥

- Having sent for engineers and surveyors together with architects.

The Brahmāndapurāna $a^{5}$ talks about surveying, several types of plans and accompanying cartography:

आरब्धास्तान्निकेतान्वै कर्तुं शीतोष्णवारणमू।

ततस्तान्निर्मयामासुः खेटानि च पुराणि च॥

ग्रामाश्वैव यथाभागं तथैव नगराणि च।

तेषामायामविष्कम्भाः सन्निवेशान्तराणि च॥

चकुस्तदा यथाज्ञानं मीत्वा मीत्वात्मनुऽझ्लेः॥

Different types of town-planning, demarcation of boundary by survey and measurement are thus alluded to in the Vāyupurāna $a^{6}$ :

नगराद्योजनं खेटं खेटाद् ग्रामोऽर्धयोजनम्।

द्विकोरां परमा सीमा क्षेत्रसीमा चतुर्घनुः ॥ 
The above facts reveal that extensive and accurate survey was carried on for the laying out and construction of different types of roads linking the various patterns of human agglomerations.

\section{CONCEPT OF GEODETIC SURVEY :}

The Śivapurāna $a^{7}$ states:

अस्त्युत्तरस्यां दिशि वै गिरीशो हिमवान् महानू ॥

पूर्वापरौ तोयनिधी सुविगाह्य स्थितो हि यः।

नानारत्नाकरो रम्यो मानद्ण्ड इव क्षितेः ॥

- There is the Himalayan mountain, esteemed like a deity, in the north of Bhārata. It stretches from the eastern ocean to the western one, as if it were a measuring rod for the measurement of the earth.

The above verse indicates that the ancient Indians had some notion of geodetic survey and this has been affirmed by concurrence of evidences and facts. The two astronomical treatises, Brahmasiddhānta ${ }^{8}$ and Somasiddhānta ${ }^{9}$, written between 500-821 A.D. bear indisputable testimony to this.

\section{CARTOGRAPHY IN THE PURĀṆAS :}

The chapter Dāna-Māhātmya of the Matsyapurāna ${ }^{10}$ furnishes abundant information about some maps or representations made with bricks, metals and other materials that were in vogue for religious purposes in the gift making ceremonies.

The Vāyu ${ }^{11}$ and Lingapurāna $a^{12}$ affirm the fact that map-making and diagram drawing were definitely known and practised, especially in connection with astronomical studies, which positively included geography also:

चक्षुः शास्त्रं जलं लेख्यं गणितं बुद्धिसत्तमाः।

पच्चेते हेतवो ज्ञेया ज्योतिर्गणविचिन्तने॥ 
- Eyes, treatises, water, maps or diagrams and mathematics or computation and survey are the five things which are instrumental in the study of stars or heavenly bodies.

All the maps of Jambudvipa and the world were prepared on sheets of metals generally for the purpose of making gifts to Brāhmaṇas for the ritual dharādāna, bhümidāna or brahmāndadāna. The Caturvargacintāmañi $i^{13}$ by Hemādri on the Matsya Purāna $a^{14}$ states:

अथातः संप्रवक्ष्यामि धरादानमनुत्तमम्।

पापक्षयकरं नृणाममाङ्ल्यविनाइानमू॥

कारयेतू पृथिवीं हैमीं जम्बुद्वीपानुकारिणीमू।

मर्यादापर्वतवतीं मध्ये मेरुसमन्विताम्॥

लोकपालाष्टकोपेतां नववर्षसमन्विताम्।

नदीनद्रातोपेतामन्ते सागरवेश्टिताम्॥

- Now I tell you the method of all-excelling Dharādāna (making gift of earth), which wipes out sin and all that is inauspicious. One should get the earth (replica or diagram or map of it) prepared of gold, having the shape of Jambudvipa with Maryādā mountains and Meru range in the centre, Lokapālas, nine varșas, hundreds of rivers and streams and encircled by ocean.

In the Bhavișyapurāna ${ }^{15}$ also three similar verses occur regarding the preparation of the map of Jambudvipa, but their diction and the tone have become more ritualistic and sacerdotal and less geographic.

According to the Brahmannda and other Purānas the dimensions of the Meru and adjoining mountains and other geographic features are very vast. To show such vast dimensions as 9000, 34000 and 40000 yojanas on the map is impossible. Hemādri ${ }^{16}$ gives the following method for representing such vast dimensions as:

अत्र रातसाहस्त्रादियोजनपरिमाणानां पृथिव्यादीनां कर्तुमशाक्यत्वात् योजनसहस्त्रस्थाने अर्धाइल्लादिमानं परिकल्य यथोक्त-संख्यातारतम्यमनुष्ठेयम्। नदीनदूतोपेतमिति नद्यो भागीरथीप्रभृतिकाः नदाः शोणाद्यः तेषां साकल्येन विधातुमराक्यत्वात् यावच्छ्छक्यमनुकारः कर्तव्यः। 
अन्ते सागरवेष्टीतामिति यद्यापि यावत्परिमाणा पृथ्वी तावानेव सागरः तथाप्यनुकारमात्रोपदेशाात् शाक्यानुकारमात्रमाचरणीयम्।

- Since it is impossible to show extremely large dimensions, for example, one lakh yojanas and so on, of the earth and its other features, it may be assumed that 1000 yojanas are represented by $1 / 2$ angula and (similarly) other dimensions can be reduced for easy representation. Again if it is not possible to show all the rivers, like Gañga and Śnna only a few important ones which can be possibly shown should be selected. Further though the dimension of the ocean is the same as that of the earth, still the former cannot be shown in totality, so it must be reduced and exhibited as much as is possible.

From this it is flagrantly evident that ancient Indians had understood and developed the concept of scale and in this sphere their knowledge, concept and methodology was almost the same as we have today.

In the Padmapurāna ${ }^{17}$ also there is a reference which informs us of the knowledge of scale where a dimension of 50 corer yojana was shown :

इत्युत्त्रवा भूपत्नी सा दास्या तामुद्धाटयत्।

मज्ञूषां तत्र संस्थं च पुस्तकं पाणिनाग्रहीी ॥

तत्रावलोकयामास साऽवतारान् समासतः।

पूर्व ततस्तु भूगोलं पश्चारात्कोटियोजनम् ॥

The following lines from the Bhavisyapurāna $a^{18}$, relating to brahmannda dāna alludes to a great reduction of the monstrous size of the Brahmāṇda through scale to make the mapping of the same possible :

तस्याओं कल्पयेद् राजन् भुवनानि चतुर्दश ।

वितस्तेरहुलडरातं यावदायामविस्तरम् ॥ 
From the above mentioned chapters of the Purānas relating to dharā or brahmāndadāna we can gather porfuse information on the construction or preparation of world map.

The Lingapurāna ${ }^{19}$ and Caturvargacintāmani $i^{20}$ tell us of preparation of world map on a gold sheet having the shape of a quadrilateral and measuring one cubit (hasta) on one of its sides. From this it is evident that ancient Indians not only had the knowledge of scale, but could show the entire earth on a flat quadrilateral just like the Mercator's projection of today:

सुवर्ण मेदिनीदानं प्रवक्ष्यामि समासतः।

पूर्वोक्तदेराकाले तु कारयेन्मुनिभिः सह ॥

लक्षणेन यथापूर्व कूपे वा मण्डपेऽथवा।

मेदिनीं कारयेद्दिव्यां सहस्रेणापि वा पुनः॥

एकहस्ता प्रकर्तव्या चतुरस्ता सुरोभना।

सतद्वीपसमुद्राद्यौः पर्वतरैभिसंवृता ॥

सर्वतीर्थसमोपेता मध्ये मेरुसमन्विता।

अथवा मध्यतो द्वीपं नवखण्डं प्रकल्पयेतू ॥

पूर्ववन्निरिल कृत्वा मण्डले वेदिमध्यतः।

सतभागैकभागेन सह तद्विधिपूर्वकम्॥

Hemādri $^{21}$ gives a very long quotation from the Brahmāndapurāna, which provides the best and most detailed description of world map drawing on a flat surface (of the earth) with the use of a scale. Moreover, there is no better recorded description of ancient Indian cartography than this.

World maps were drawn for other than sacerdotal purpose is evident from the Padmapuranna $a^{22}$. It also reveals that these maps were prepared and maintained in a book form and kept with care and this practice appears to have been in vogue prior to Ptolemy (150 A.D.). It is clear from this that ancient Indians prepared Atlases also.

The Bhavișyapurāna $a^{23}$ goes a step further and delineates about the map of the fourteen bhuvanas also. This bhuvana map was 
prepared on a square piece of cloth, which had a side measuring nearly eleven feet. Thus it totally resembled a large-sized wall map of today :

\section{सप्तहस्तं पटं कृत्वा चतुरस्त्रं सुसंहतम्। \\ अभिन्नाझं हढं शुद्धं शुद्धस्फुटिकवर्चसम्॥ \\ प्रारंभं कारयेद्राजतत्पटे तस्मिन्यथोदितम्। \\ मध्ये च लेखयेद् राजाअम्बूद्वीपं सविस्तरमू॥ \\ तस्य मध्ये स्थितो मेरुर्मेरीरुपरि देवताः। \\ दिशासु लोकपात्लानां पुरोष्टौ सुरसंयुताः॥ \\ सपद्वीपवती पृथ्वी सत्त चैव कुलाचलाः। \\ सागराः सत्त चात्रेव नद्यो हृदा सरांसि च॥}

As part of brahmanndadāna ceremony the map of the whole universe was constructed in the shape of two hemispheres aspiring to be true to scale and joined together. Thus we come to know that our ancients also made Globes ${ }^{24}$.

\section{CONCLUSION :}

The above textual articulations indicate the expertise of Pauranic Indians in the art of surveying and map-making. The westerner, F. Wilford ${ }^{25}$, also records that he has seen the map of the world and various other maps prepared according to the Pauranics and Indian astronomers. Therefore, the above citations concurrently prove without a doubt that these maps must have been in vogue from very ancient times.

\section{Endnotes :}

1. Matsyapurāna, V. 10.

2. Varāhapurāna, VII. 6.

3. Viṣnupurāṇa, I. 13. 82-4.

4. Brahmapurāna, 47. 2-3.

5. Brahmānḍ̂purāna, Pūrvabhāga. VII. 93-5.

6. Vāyupurāna, VIII. 117.

7. Śivapurāna, II. 3. 1. 14-6. 
8. Brahmasiddhānta, p. 12, v. 93: वृत्तस्य षण्णवत्यंशो द्ण्डवच्च समः स तत्।

9. Somasiddhānta, p. 6, v. 1: भचकात् षण्णवत्यंशा समभूया च सैव हि।

10. Matsyapurāṇa, Ch. 83.

11. Vāyupurāṇa, 52. 123.

12. Lingapurāṇa, 61. 62-3.

13. Caturvargacintāmaṇi, Dānakhaṇḍa, p. 290.

14. Matsyapurāna, 284. 1-3.

15. Bhaviṣyapurāṇa, 165. 8-10.

16. Caturvargacintāmaṇi, Dānakhaṇda, p. 297.

17. Padmapurāna, Uttarakhāṇḍa, 217. 4-5.

18. Bhavișyapurāna, 177. 6.

19. Liñgapurāṇa, Uttarabhāga, 32. 1-6.

20. Caturvargacintāmaṇi, Dānakhaṇḍa, p. 296.

21. Ibid., p. 307-10.

22. Padmapurāṇa, Uttarakhāṇḍa, 217. 1-9.

23. Bhavișyapurāṇa, 191. 7-24.

24. Ibid., 177. 3-8.

25. Asiatic Researches, Vol. VIII, p. 270-71; Vol. X, p. 140.

\section{BIBLIOGRAPHY:}

1. Agni Purāna, Text with Eng. tr. by M.N. Dutt, Parimal Publications, Delhi, 2001.

2. Brahma Purāṇa, Rajendranath Sharma, Nag Publishers, New Delhi, 2007.

3. Brahmāṇda Purāna, Chowkhamba Krishnadas Academy, Anandasrama Publications, Varanasi, 2012.

4. Brahmasiddhānta, ed. by Vindheswari Prasad Dvivedi, Chowkambha Sanskrit Series, 1912.

5. Brahmavaivarta Purāna, Text with Eng. tr. By Sen Rajendranath, The Panini Office, Bhuvaneswari Ashram, Bhadurganj, Allahabad, 1920.

6. Bhāgavata Purāna, Text with Eng. tr. by C.L. Goswami, Gita Press, Gorakhpur, 1971.

7. Bhaviṣya Purāṇa, Venkatesvara Press, 1953. 
8. Caturvargacintāmaṇi, by Hemādri, ed. by Pandit Sadāśiva Dīkșita, Varanasi, 1902.

9. Garuḍa Purāṇa,Text with Eng. tr. by M.N. Dutt, New Bharatiya Book Corporation, Delhi, 2007.

10. Linga Purāna, Text with Eng. tr. by Nagar Shanti Lal, Parimal Sanskrit Series N0.114, Parimal Publications, Delhi, 2011.

11. Manudharmaśāstra, by K. Motwani, Ganesh \& Co. publishers, Madras, 1958.

12. Matsya Purāna, Text with Eng. tr. by a Board of scholars, Parimal Publication, Delhi, 2007.

13. Padma Purāna, ed. by Rao Sahib Mandate and Visvanath Narayana, Anandasrama Press, 1894.

14. Śiva Purāna, Text with Eng. tr. by Sharma Sudarshan Kumar, Parimal Publications, Delhi, 2008.

15. Somasiddhānta Sañgraha, ed. by Vindheswari Prasad Dvivedi, Chowkambha Sanskrit Series, 1912.

16. Vāyu Purāna, Text with Eng. tr. by Sharma Sudarshan Kumar, Parimal Publications, Delhi, 2008.

17. Varāha Purāna, Text with Eng. tr. by Ahibhushan Bhattacharya, All India Kasiraj Trust, Varanasi, 1981.

18. Viṣnu Purāṇa, Text with Eng. tr. by Wilson H.H, Parimal Publications, Delhi, 2011.

19. Viṣnudharmottara Purāna, Venkatesvara Press, 1913.

20. Asiatic Researches or Transactions of the Society instituted in Bengal, Vol. VIII and X, London, 1808 and 1811. 